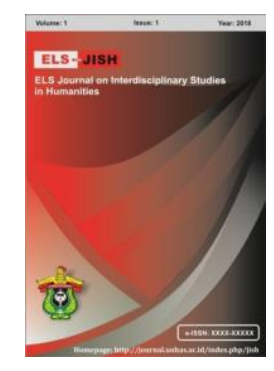

ELS-JISH

ELS Journal on Interdisciplinary Studies on Humanities

Volume 3 Issue 1, 2020

ISSN (print) : 2621-0843

ISSN (online) : 2621-0835

Homepage : http://journal.unhas.ac.id/index.php/jish

\title{
The Effect of Using Drama Technique towards the Students' Speaking Accuracy, Fluency, and Comprehensibility
}

\begin{abstract}
Julia Marfuah ${ }^{1}$, Andi Patmasari ${ }^{2}$
²apatmasari@gmail.com

Abstract

This research intended to prove whether the use of drama technique affected the students' speaking accuracy, fluency, and comprehensibility or not. This research employed quasiexperimental research design with the non-equivalent control group design. The population of this research was the second year students of senior high school that consisted of 260 students. This research used cluster random sampling technique. From nine classes, two classes were taken as a sample of the research. One class was chosen as the experimental class and another one as the control class. The total sample consisted of 72 students. In order to answer the research question, the instrument of this research was speaking test. The result of data analysis showed that there was no significant different of the students' speaking accuracy, fluency, and comprehensibility of both classes in pre-test. But the students' speaking accuracy, fluency, and comprehensibility of both classes in post-test was significant, which means that drama technique can significantly affect the students' speaking accuracy, fluency, and comprehensibility.
\end{abstract}

Keywords: Drama, Accuracy, Fluency, Comprehensibility, Speaking Ability

How to cite: Marfuah, J. \& Patmasari, A. (2020). The effect of using drama technique towards the students' speaking accuracy, fluency, and comprehensibility. ELS Journal on Interdisciplinary Studies in Humanities, 3(1), 97-109. DOI: http://dx.doi.org/10.34050/elsjish.v3i1.9634

\section{Introduction}

The aims of language teaching courses are very commonly defined in terms of four language skills; listening, speaking, reading, and writing. These four skills should be mastered by the students if they want to get success in English. Besides, it is essential to consider that speaking is supported by some components; they are accuracy, fluency, and comprehensibility. The students who master the three components can easily perform their speaking. Widdowson (1985) describes that the act of communication through speaking is commonly performed in face-to-face interaction and occurs as part dialogue or other forms of verbal exchange.

Teaching speaking is very important part in language learning. The ability to communicate clearly and efficiently contributes to the success of the students

${ }^{1,2}$ Universitas Tadulako, Indonesia. 
in school and in every phase of their life. Therefore, it is essential that language teacher pays great attention in teaching speaking so that the teacher should make various activities in teaching speaking to students; the teacher should motivate students to master speaking.

There are many kinds of technique and method to teach speaking. Drama is one of them. Using drama in foreign language class has many advantages. Cunico (2005) states, "Drama is under-exploited resource in the foreign language classroom for promoting intercultural competence and developing awareness of the interpersonal dimension embedded in the language we use." If drama is considered as a teaching method in the sense of being part of the eclectic approach to language teaching, then it can be a main aid in the acquisition of communicative competence (Davis, 1990).

Furthermore, Samantaray (2014) adds, "By using drama technique to teach English, the monotony of a conventional English class can be broken and the syllabus can be transformed into one which prepares learners to face their immediate world better as competent users of the English language because they get an opportunity to use the language in operation." Teaching English subject using drama is effective in the development of students' creative thinking (Albalawi, 2014).

Based on the background, the research question examined in this research was:

How was the effect of using drama technique towards the students' speaking accuracy, fluency, and comprehensibility?

\section{Method}

This research employed quasi-experimental research design with the nonequivalent control group design. Gay, Mills, and Airasian (2006) stated, "In nonequivalent control group design, two (or more) treatment groups are pretested, administered a treatment, and posttested." This design takes the following form:

\begin{tabular}{|lll|}
\hline 0 & $X 1$ & 0 \\
0 & $X 2$ & 0 \\
\hline
\end{tabular}

Note:

$\mathrm{O}=$ test, pretest, or posttest

$\mathrm{X} 1=$ unusual treatment

$\mathrm{X} 2=$ control treatment

(Gay, Mills, and Airasian, 2006)

The independent variable in this research was the use of drama technique and the dependent variable was the students' speaking accuracy, fluency, and comprehensibility.

The population of this research was the second year students of senior high school that consisted of 260 students. This research used cluster random sampling technique. From nine classes, two classes were taken as a sample of the research. One class was chosen as the experimental class and another one as the control class. The total sample consisted of 72 students. 
In order to answer the research question, the instrument of this research was speaking test. There are a lot of oral techniques, but this research used a picture or picture story. The tests administered before and after exposing students to the use of drama technique. The pre-test was intended to see the students' prior knowledge on speaking before giving treatment and the post-test administered to know the students' speaking ability after the treatment using drama technique.

\section{Findings}

In order to answer the research question, the instrument of this research was speaking test. There are a lot of oral techniques, but this research used a picture or picture story. Furthermore, the description of the students' speaking ability covering three elements of speaking, they were accuracy, fluency, and comprehensibility. The results of the tests can be seen as in the following tables.

\subsection{Accuracy}

The criteria use for defining accuracy includes components such as grammar, vocabulary, and pronunciation. Accuracy refers to producing correct sentences by putting correct vocabulary and grammar.

\subsubsection{The Rate Percentage and Frequency of the Students' Speaking Accuracy}

The rate percentage and frequency of the students' speaking accuracy were presented in the following tables.

Table 1. The Rate Percentage and Frequency of the Students' Speaking Accuracy in Experimental Class

\begin{tabular}{rlrrrr}
\hline \multirow{2}{*}{ No } & Classification & Prequency & $\begin{array}{c}\text { Percentage } \\
(\%)\end{array}$ & Frequency & $\begin{array}{c}\text { Percentage } \\
(\%)\end{array}$ \\
\cline { 3 - 6 } & Excellent & 1 & $2.8 \%$ & 2 & $5.6 \%$ \\
\hline 1 & Very good & 0 & $0 \%$ & 0 & $0 \%$ \\
\hline 3 & Good & 4 & $11.1 \%$ & 14 & $38.9 \%$ \\
\hline 4 & Fairly good & 18 & $50.0 \%$ & 12 & $33.3 \%$ \\
\hline 5 & Fair & 0 & $0 \%$ & 0 & $0 \%$ \\
\hline 6 & Poor & 13 & $36.1 \%$ & 8 & $22.2 \%$ \\
\hline 7 & Very poor & 0 & $0 \%$ & 0 & $0 \%$ \\
\hline & Total & $\mathbf{3 6}$ & $\mathbf{1 0 0} \%$ & $\mathbf{3 6}$ & $\mathbf{1 0 0} \%$ \\
\hline
\end{tabular}

Table 1 shows the students' speaking accuracy in experimental class before the treatment was given to the students, there was 1 student $(2.8 \%)$ got "Excellent", 4 students (11.1\%) got "Good", 18 students (50.0\%) got "Fairly Good", and 13 students (36.1\%) got "Poor". After the treatment was given, there were 2 students (5.6\%) got "Excellent", 14 students (38.9\%) got "Good", 12 students (33.3\%) got "Fairly Good", and 8 students (22.2\%) got "Poor". 
Table 2. The Rate Percentage and Frequency of the Students' Speaking Accuracy in Control Class

\begin{tabular}{rlrrrr}
\hline \multirow{2}{*}{ No } & Classification & Frequency & $\begin{array}{c}\text { Percentage } \\
(\%)\end{array}$ & Frequency & $\begin{array}{c}\text { Percentage } \\
(\%)\end{array}$ \\
\cline { 3 - 6 } & Excellent & 2 & $5.6 \%$ & 0 & $0 \%$ \\
\hline 1 & Very good & 0 & $0 \%$ & 0 & $0 \%$ \\
\hline 3 & Good & 2 & $5.6 \%$ & 8 & $22.2 \%$ \\
\hline 4 & Fairly good & 14 & $38.9 \%$ & 16 & $44.4 \%$ \\
\hline 5 & Fair & 0 & $0 \%$ & 0 & $0 \%$ \\
\hline 6 & Poor & 17 & $47.2 \%$ & 12 & $33.3 \%$ \\
\hline 7 & Very poor & 1 & $2.8 \%$ & 0 & $0 \%$ \\
\hline & Total & $\mathbf{3 6}$ & $\mathbf{1 0 0} \%$ & $\mathbf{3 6}$ & $\mathbf{1 0 0 \%}$ \\
\hline
\end{tabular}

Table 2 shows the students' speaking accuracy in control class, there were 2 students (5.6\%) got "Excellent", 2 students (5.6\%) got "Good", 14 students (38.9\%) got "Fairly Good", 17 students (47.2\%) got "Poor", and 1 student $(2.8 \%)$ got "Very Poor". On post-test, there were 8 students $(22.2 \%)$ got "Good", 16 students (44.4\%) got "Fairly Good", and 12 students (33.3\%) got "Poor".

\subsubsection{The Mean Score and Standard Deviation of the Students' Speaking Accuracy}

After calculating the data of both classes, the mean score and standard deviation of both classes were presented the following tables.

Table 3. The Mean Score and Standard Deviation of the Students' Speaking Accuracy in Pre-Test

\begin{tabular}{ccc}
\hline Class & Mean Score & Standard Deviation \\
\hline Experimental & 3.81 & 0.75 \\
\hline Control & 3.64 & 0.87
\end{tabular}

Table 3 shows in pre-test, the mean score of the students' speaking accuracy in experimental class was 3.81 and the standard deviation was 0.75 , while in control class, the mean score was 3.64 and the standard deviation was 0.87 .

Table 4. The Mean Score and Standard Deviation of the Students' Speaking Accuracy in Post-Test

\begin{tabular}{ccc}
\hline Class & Mean Score & Standard Deviation \\
\hline Experimental & 4.31 & 0.89 \\
\hline Control & 3.89 & 0.75 \\
\hline
\end{tabular}

Table 4 shows in post-test, the mean score of the students' speaking accuracy in experimental class was 4.31 and the standard deviation was 0.89 , while in control class, the mean score was 3.89 and the standard deviation was 0.75 . 


\subsubsection{The T-Test Value of Students' Speaking Accuracy}

In order to know whether or not the mean score is different from the two variables at the level of significance 0.05 with degrees of freedom (df) $=n 1+n 2-$ 2 , t-test for independent sample was employed.

The following table shows the result of the calculation.

Table 5. The Value of T-test of the Students' Speaking Accuracy

\begin{tabular}{ccc} 
Variable & T-Test & T-Table \\
\hline Pre-test & 0.85 & 1.980 \\
\hline Post-test & 2.01 & 1.980 \\
\hline
\end{tabular}

Table 5 shows in pre-test, the value of t-test $(0.85)$ was smaller than the value of t-table (1.980). Based on this finding, it can be concluded that there was no significant different between the mean score of the students' pre-test from both classes. From the data shows in table 5, it was also clear that the value of t-test (2.01) was higher than the value of t-table (1.980). Based on this finding, it can be inferred that the difference between the students' speaking accuracy of both classes in post-test was significant, which means that drama technique can significantly affect the students' speaking accuracy.

\subsection{Fluency}

Fluency refers to be able to communicate the ideas without thinking too much about the things to say or having to stop. Fluency is indicated by natural fast speed of speaking and only little number pauses.

\subsubsection{The Rate Percentage and Frequency of the Students' Speaking Fluency}

The rate percentage and frequency of the students' speaking fluency were presented in the following tables.

Table 6. The Rate Percentage and Frequency of the Students' Speaking Fluency in Experimental Class

\begin{tabular}{rlrrrr}
\hline \multirow{2}{*}{ No } & Classification & \multicolumn{2}{c}{ Pre-test } & \multicolumn{2}{c}{ Post-test } \\
\cline { 3 - 6 } & Frequency & $\begin{array}{c}\text { Percentage } \\
(\%)\end{array}$ & Frequency & $\begin{array}{c}\text { Percentage } \\
(\%)\end{array}$ \\
\hline 1 & Excellent & 2 & $5.6 \%$ & 6 & $16.7 \%$ \\
\hline 2 & Very good & 0 & $0 \%$ & 0 & $0 \%$ \\
\hline 3 & Good & 6 & $16.7 \%$ & 17 & $47.2 \%$ \\
\hline 4 & Fairly good & 8 & $22.2 \%$ & 12 & $33.3 \%$ \\
\hline 5 & Fair & 0 & $0 \%$ & 0 & $0 \%$ \\
\hline 6 & Poor & 19 & $52.8 \%$ & 1 & $2.8 \%$ \\
\hline 7 & Very poor & 1 & $2.8 \%$ & 0 & $0 \%$ \\
\hline & Total & $\mathbf{3 6}$ & $\mathbf{1 0 0} \%$ & $\mathbf{3 6}$ & $\mathbf{1 0 0} \%$ \\
\hline
\end{tabular}

Table 6 shows the students' speaking fluency before the treatment was given, there were 2 students (5.6\%) got "Excellent", 6 students $(16.7 \%)$ got "Good", 8 
students (22.2\%) got "Fairly Good", 19 students (52.8\%) got "Poor", and 1 student $(2.8 \%)$ got "Very Poor". And after the treatment was given, there were 6 students (16.7\%) got "Excellent", 17 students (47.2\%) got "Good", 12 students $(33.3 \%)$ got "Fairly Good", and 1 student $(2.8 \%)$ got "Poor".

Table 7. The Rate Percentage and Frequency of the Students' Speaking Fluency in Control Class

\begin{tabular}{rlrrrr}
\hline \multirow{2}{*}{ No } & Classification & \multicolumn{2}{c}{ Pre-test } & \multicolumn{2}{c}{ Post-test } \\
\cline { 3 - 6 } & Frequency & $\begin{array}{c}\text { Percentage } \\
(\%)\end{array}$ & Frequency & $\begin{array}{c}\text { Percentage } \\
(\%)\end{array}$ \\
\hline 1 & Excellent & 1 & $2.8 \%$ & 4 & $11.1 \%$ \\
\hline 2 & Very good & 0 & $0 \%$ & 0 & $0 \%$ \\
\hline 3 & Good & 8 & $22.2 \%$ & 12 & $33.3 \%$ \\
\hline 4 & Fairly good & 15 & $41.7 \%$ & 11 & $30.6 \%$ \\
\hline 5 & Fair & 0 & $0 \%$ & 0 & $0 \%$ \\
\hline 6 & Poor & 12 & $33.3 \%$ & 9 & $25.0 \%$ \\
\hline 7 & Very poor & 0 & $0 \%$ & 0 & $0 \%$ \\
\hline & Total & $\mathbf{3 6}$ & $\mathbf{1 0 0} \%$ & $\mathbf{3 6}$ & $\mathbf{1 0 0} \%$ \\
\hline
\end{tabular}

Table 7 shows the students' speaking fluency in the control class, there were 1 student (2.8\%) got "Excellent", 8 students (22.2\%) got "Good", 15 students $(41.7 \%)$ got "Fairly Good", and 12 students (33.3\%) got "Poor". On post-test, there were 4 students (11.1\%) got "Excellent", 12 students (33.3\%) got "Good", 11 students (30.6\%) got "Fairly Good", and 9 students $(25.0 \%)$ got "Poor".

\subsubsection{The Mean Score and Standard Deviation of the Students' Speaking Fluency}

After calculating the data of both classes, the mean score and standard deviation of both classes were presented the following tables.

Table 8. The Mean Score and Standard Deviation of the Students' Speaking Fluency in Pre-Test

\begin{tabular}{ccc}
\hline Class & Mean Score & Standard Deviation \\
\hline Experimental & 3.69 & 0.98 \\
\hline Control & 3.97 & 0.88
\end{tabular}

Table 8 shows in pre-test, the mean score of the students' speaking fluency in the experimental class was 3.69 and the standard deviation was 0.98 , while in the control class, the mean score was 3.97 and the standard deviation was 0.88 .

Table 9. The Mean Score and Standard Deviation of the Students' Speaking Fluency in Post-Test

\begin{tabular}{ccc}
\hline Class & Mean Score & Standard Deviation \\
\hline Experimental & 4.78 & 0.78 \\
\hline Control & 4.31 & 0.98 \\
\hline
\end{tabular}


Table 9 shows in post-test, the mean score of the students' speaking fluency in the experimental class was 4.78 and the standard deviation was 0.78 , while in the control class, the mean score was 4.31 and the standard deviation was 0.98 .

\subsubsection{The T-Test Value of Students' Speaking Fluency}

In order to know whether or not the mean score is different from the two variables at the level of significance 0.05 with degrees of freedom (df) $=n 1+n 2-$ 2 , t-test for independent sample was employed.

The following table shows the result of the calculation.

Table 10. The Value of T-test of the Students' Speaking Fluency

\begin{tabular}{ccc}
\hline Variable & T-Test & T-Table \\
\hline Pre-test & -0.97 & 1.980 \\
\hline Post-test & 2.24 & 1.980 \\
\hline
\end{tabular}

Table 10 shows in pre-test, the value of t-test $(-0.97)$ was smaller than the value of t-table (1.980). Based on this finding, it can be concluded that there was no significant different between the mean score of the students' pre-test from both classes. From the data shows in table 10, it was also clear that the value of ttest (2.24) was higher than the value of t-table (1.980). Based on this finding, it can be inferred that the difference between the students' speaking fluency of both classes in post-test was significant, which means that drama technique can significantly affect the students' speaking fluency.

\subsection{Comprehensibility}

Comprehensibility deals with the awareness of the overall meaning conveyed by the speaker without of need too much attention in the individual linguistic and paralinguistic features in the speech signal.

\subsubsection{The Rate Percentage and Frequency of the Students' Speaking Comprehensibility}

The rate percentage and frequency of the students' speaking comprehensibility were presented in the following tables.

Table 11. The Rate Percentage and Frequency of the Students' Speaking Comprehensibility in Experimental Class

\begin{tabular}{rlrrrr}
\hline \multirow{2}{*}{ No } & Classification & \multicolumn{2}{c}{ Pre-test } & \multicolumn{2}{c}{ Post-test } \\
\cline { 3 - 6 } & & Frequency & Percentage (\%) & Frequency & $\begin{array}{c}\text { Percentage } \\
(\%)\end{array}$ \\
\hline 1 & Excellent & 1 & $2.8 \%$ & 7 & $19.4 \%$ \\
\hline 2 & Very good & 0 & $0 \%$ & 0 & $0 \%$ \\
\hline 3 & Good & 13 & $36.1 \%$ & 21 & $58.3 \%$ \\
\hline 4 & Fairly good & 15 & $41.7 \%$ & 8 & $22.2 \%$ \\
\hline 5 & Fair & 0 & $0 \%$ & 0 & $0 \%$ \\
\hline 6 & Poor & 7 & $19.4 \%$ & 0 & $0 \%$ \\
\hline 7 & Very poor & 0 & $0 \%$ & 0 & $0 \%$ \\
\hline & Total & $\mathbf{3 6}$ & $\mathbf{1 0 0} \%$ & $\mathbf{3 6}$ & $\mathbf{1 0 0} \%$ \\
\hline
\end{tabular}


Table 11 shows the students' speaking comprehensibility in experimental class before the treatment was given, there were 1 student $(2.8 \%)$ got "Excellent", 13 students (36.1\%) got "Good", 15 students (41.7\%) got "Fairly Good", and 7 students (19.4\%) got "Poor". And after the treatment was given, there were 7 students (19.4\%) got "Excellent", 21 students (58.3\%) got "Good", and 8 students $(22.2 \%)$ got "Fairly Good".

Table 12. The Rate Percentage and Frequency of the Students' Speaking Comprehensibility in Control Class

\begin{tabular}{rlrrrrr}
\hline \multirow{2}{*}{ No } & Classification & Frequency & $\begin{array}{c}\text { Percentage } \\
(\%)\end{array}$ & Frequency & $\begin{array}{c}\text { Percentage } \\
(\%)\end{array}$ \\
\cline { 3 - 7 } & Excellent & 1 & $2.8 \%$ & 4 & $11.1 \%$ \\
\hline 1 & Very good & 0 & $0 \%$ & 0 & $0 \%$ \\
\hline 3 & Good & 4 & $11.1 \%$ & 9 & $25.0 \%$ \\
\hline 4 & Fairly good & 24 & $66.7 \%$ & 19 & $52.8 \%$ \\
\hline 5 & Fair & 0 & $0 \%$ & 0 & $0 \%$ \\
\hline 6 & Poor & 7 & $19.4 \%$ & 4 & $11.1 \%$ \\
\hline 7 & Very poor & 0 & $0 \%$ & 0 & $0 \%$ \\
\hline & Total & $\mathbf{3 6}$ & $\mathbf{1 0 0} \%$ & $\mathbf{3 6}$ & $\mathbf{1 0 0} \%$ \\
\hline
\end{tabular}

Table 12 shows the students' speaking comprehensibility in the control class, there were 1 student (2.8\%) got "Excellent", 4 students (11.1\%) got "Good", 24 students (66.7\%) got "Fairly Good", and 7 students $(19.4 \%)$ got "Poor". And after the treatment was given, there were 4 students $(11.1 \%)$ got "Excellent", 9 students (25.0\%) got "Good", 19 students (52.8\%) students got "Fairly Good", and 4 students (11.1\%) got "Poor".

\subsubsection{The Mean Score and Standard Deviation of the Students' Speaking Comprehensibility}

After calculating the data of both classes, the mean score and standard deviation of both classes were presented the following tables.

Table 13. The Mean Score and Standard Deviation of the Students' Speaking Comprehensibility in Pre-Test

\begin{tabular}{ccc}
\hline Class & Mean Score & Standard Deviation \\
\hline Experimental & 4.22 & 0.79 \\
\hline Control & 3.97 & 0.66
\end{tabular}

Table 13 shows in pre-test, the mean score of the students' speaking comprehensibility in the experimental class was 4.22 and the standard deviation was 0.79 , while in the control class, the mean score was 3.97 and the standard deviation was 0.66 . 
Table 14. The Mean Score and Standard Deviation of the Students' Speaking Comprehensibility in Post-Test

\begin{tabular}{ccc}
\hline Class & Mean Score & Standard Deviation \\
\hline Experimental & 4.97 & 0.66 \\
\hline Control & 4.36 & 0.83
\end{tabular}

Table 14 shows in post-test, the mean score of the students' speaking comprehensibility in the experimental class was 4.97 and the standard deviation was 0.66 , while in the control class, the mean score was 4.36 and the standard deviation was 0.83 .

\subsubsection{The T-Test Value of Students' Speaking Comprehensibility}

In order to know whether or not the mean score is different from the two variables at the level of significance 0.05 with degrees of freedom $(\mathrm{df})=\mathrm{n} 1+\mathrm{n} 2$ 2 , t-test for independent sample was employed.

The following table shows the result of the calculation.

Table 15. The Value of T-test of the Students' Speaking Comprehensibility

\begin{tabular}{ccc}
\hline Variable & T-Test & T-Table \\
\hline Pre-test & 1.39 & 1.980 \\
\hline Post-test & 3.39 & 1.980
\end{tabular}

Table 15 shows in pre-test, the value of t-test (1.39) was smaller than the value of t-table (1.980). Based on this finding, it can be concluded that there was no significant different between the mean score of the students' pre-test from both classes. From the data shows in table 15 , it was also clear that the value of $t$ test (3.39) was higher than the value of $t$-table (1.980). Based on this finding, it can be inferred that the difference between the students' speaking comprehensibility of both classes in post-test was significant, which means that drama technique can significantly affect the students' speaking comprehensibility.

\section{Discussion}

Another crucial thing to be discussed in this research was the major mistakes of the students' speaking accuracy, fluency, and comprehensibility. The data of this research showed that there was difference of the students' speaking accuracy, fluency, and comprehensibility.

\subsection{The Students' Speaking Accuracy}

Basically, the students' speaking accuracy was classified poor in pre-test. The researcher found that there were some factors influencing the students' speaking accuracy, namely their mother tongue, mispronunciation, grammar, and less vocabulary. The main component that influences the students in speaking performance was their pronunciation, grammar, and vocabulary.

\subsubsection{Pronunciation}

Pronunciation is the way in which a language or a particular word or sound is pronounced. It influences the quality of the students' ability to speak English. 
Some mispronunciations appear when the students pronunce the words because they were influenced by the mother tongue as their first language. For example:
Palace /'paleis/ should be /'pæl.Is/
Live /larv/ should be /Irv/
Carried/ker.id/ should be /'kær.id/
Said /said/ should be /sed/
Wear /wiar/ should be /weə r /

\subsubsection{Grammar}

Grammar also plays an important role to the students' speaking quality. The quality of students' speaking ability will be better if they have a good structure. The researcher found some errors in students' grammar in speaking performance test, for example:

Cinderella goes to the party should be Cinderella went to the party

Cinderella leave the palace should be Cinderella left the palace

Uncle Alip hospitalized should be Uncle Alip was hospitalized

The thieves was ran should be The thieves ran

That man not care with him and just go should be The man didn't care about him and just went away

He eventually took to hospital should be He was eventually taken to the hospital

It can be said that most of the students acquired errors in grammar during speaking performance in pre-test. And the students got better result after having treatment. Actually, the students were success to decrease their grammar errors during speaking performance in post-test. And the students arranged sentences better than before.

\subsubsection{Vocabulary}

Vocabulary is all the words that a person knows or uses. Using appropriate vocabularies can help students to produce good sentences. The examples of errors in word choice (vocabulary) are:

Her step mother and stepsisters don't want Cinderella go to the prince party should be Her stepmother and stepsisters forbid Cinderella to go to the prince party

Then came someone with black wear should be Then someone with black suit came

Her jacket and purse in take by two that people should be His jacket and wallet were taken by the two men

Then two people passed the old man passed the road should be Then, the two men went across the road but didn't help the old man 
Seeing the example above, it can be noticed that the students were less stock of the word and diction. Therefore, they did some wrong words choice which they believe that they had used appropriate words but in fact they produced inappropriate words. After using humorous drama technique, the students' vocabulary attained an enhancement in expressing their idea.

\subsection{The Students' Speaking Fluency}

Fluency refers to be able to communicate the ideas without thinking too much about the things to say or having to stop. Fluency is indicated by natural fast speed of speaking and only little number pauses. Low achievement of the students' speaking fluency sometimes is caused by the topics which are unfamiliar for them.

The examples of the filler that were usually used by the students are:

Ee... one day, ee... the kingdom had a dancing party ee...

One day, a prince made mmm... an announcement

At the party, emmm... she meet the prince and dancing ee... with the prince

Based on the example above, the students' speaking fluency were still low. Some of the students made many unnatural pauses. Therefore, when they thought certain words to express their idea, the filler suddenly appear from their mouth. It caused by less of vocabulary of the students so sometimes they didn't know what they wanted to say. Unfortunately, the students' filler were decrease after having treatment. The students trained to speak relax and well, so that they didn't make any unnatural pauses. They arranged the word and said it well.

\subsection{The Students' Speaking Comprehensibility}

Some of the students didn't know how to make their sentences easy to understand. The researcher found that the students' speaking comprehensibility was influenced by the picture given to them. Some of them were speechless and didn't know what they wanted to tell about the picture during pre-test. But, the students' speaking comprehensibility enhanced after giving the treatment.

The result of experimental class was higher than the control class. This finding suggest that drama technique is one of the best techniques in teaching speaking. Drama can be applied in teaching speaking. It can draw learners' attention to focus on creating dramatic situations.

These findings were supported by some researchers who have already done research in the field of drama. Syamsinar (2004) found that most of students of SMAN 1 Belawa have favorable interest because most of them agree with the positive statement and disagree with the negative ones about learning speaking through drama teaching techniques. Indrawaty (2010) who was conducted a research under the title "Minimizing English Pronunciation of the Second Year Students of SMAN 1 Camba by Using Drama Text" concluded that by using drama, students can increase their self confidence, express their feelings, ideas, and thought. 


\section{Conclusions}

In terms of accuracy, in pre-test, the value of t-test $(0.85)$ was smaller than the value of t-table (1.980). It means that there was no significant different between the mean score of the students' pre-test from both classes. But, the value of t-test (2.01) was higher than the value of t-table (1.980). So, it can be inferred that the difference between the students' speaking accuracy of both classes in post-test was significant, which means that drama technique can significantly affect the students' speaking accuracy.

In terms of fluency, in pre-test, the value of t-test $(-0.97)$ was smaller than the value of t-table (1.980); in post-test, the value of t-test (2.24) was higher than the value of t-table (1.980). Based on these findings, it can be concluded that there was no significant different between the mean score of the students' pre-test from both classes, but the students' speaking fluency of both classes in post-test was significant, which means that drama technique can significantly affect the students' speaking fluency.

In terms of comprehensibility, there was no significant different between the mean score of the students' pre-test from both classes. However, the students' speaking comprehensibility of both classes in post-test was significant, which means that drama technique can significantly affect the students' speaking comprehensibility.

Considering the result of this research, it is suggested for the English teacher to apply drama to stimulate the students' attention and motivate them in learning English. For the future researchers, the duration of the treatment in the present research was rather short, so further research with longer intervention should be carried out.

\section{References}

Albalawi, B. R. (2014). Effectiveness of teaching English subject using drama on the development of students' creative thinking. IOSR Journal of Research and Method in Education (IOSR-JRME). 4(6), 54-63.

Cunico, S. (2005). Teaching language and intercultural competence through drama: Some suggestions for neglected resource. Language Learning Journal, 31(1), 21-29.

Davis, P. (1990). The use of drama in english language teaching. TESL Canada Journal, 8(1), 87-99.

Gay, L. R., Mills, G. E., and Airasian, P. (2006). Education research: Competencies for analysis and applications. New Jersey: Merrill Prentice Hall.

Indrawaty, I. (2010). Minimizing English pronunciation of the second year students of SMAN 1 Camba by using drama text (Unpublished thesis). State University of Makassar, Makassar.

Samantaray, P. (2014). Dramatization as a method of developing spoken english skill. International Journal of Language and Linguistics, 1(1), 7078 . 
Syamsinar. (2004). Developing speaking ability of the second year students of SMAN 1 Belawa through drama (Unpublished thesis). State University of Makassar, Makassar.

Widdowson, H. G. (1985). Teaching language as communication. Oxford: Oxford University Press. 